\title{
Oil Recovery from Fractionated Dried Distillers Grains with Solubles (DDGS) Using Enzymes
}

\author{
Md. Sanaul Huda, Nurun Nahar *(D), Ewumbua Monono and Sagar Regmi
}

Citation: Huda, M.S.; Nahar, N.; Monono, E.; Regmi, S. Oil Recovery from Fractionated Dried Distillers Grains with Solubles (DDGS) Using Enzymes. Processes 2021, 9, 1507. https://doi.org/10.3390/pr9091507

Academic Editor: Farid B. Cortés

Received: 30 July 2021

Accepted: 25 August 2021

Published: 26 August 2021

Publisher's Note: MDPI stays neutral with regard to jurisdictional claims in published maps and institutional affiliations.

Copyright: (c) 2021 by the authors. Licensee MDPI, Basel, Switzerland. This article is an open access article distributed under the terms and conditions of the Creative Commons Attribution (CC BY) license (https:// creativecommons.org/licenses/by/ $4.0 /)$.
Department of Agricultural and Bio-Systems Engineering, North Dakota State University, Fargo, ND 58108, USA; mdsanaul.huda@ndsu.edu (M.S.H.); ewumbua.monono@ndsu.edu (E.M.); sagar.regmi@ndsu.edu (S.R.)

* Correspondence: nurun.nahar@ndsu.edu; Tel.: +1-701-231-7140

\begin{abstract}
Oil recovered from dried distillers grain with solubles (DDGS) can be a high-value product over animal feed to provide an additional profit to ethanol plants currently operating at slim profit margins. Fractionations of DDGS and enzymatic hydrolysis were considered in this study to improve the oil recovery from DDGS. A combination of sieving and then air aspiration was used to separate the original DDGS into three different fractions: light, medium, and heavy. The heavier fraction had up to $24 \%$ increased oil content compared to the original DDGS. Commercial enzymes, protease, cellulase, and hemicellulase were tested separately and in combinations at $55^{\circ} \mathrm{C}$ for $3 \mathrm{~h}$ at $130 \mathrm{rpm}$ to determine their effect on oil recovery from the original and fractionated DDGS. Oil recovery was significantly improved (around 20\%) following enzyme hydrolysis of the sieved aspirated heavy fractions of DDGS compared to the original DDGS. More than $90 \%$ of oil recovery was achieved by using a combination of cellulase and protease enzymes. Increasing the temperature above $55{ }^{\circ} \mathrm{C}$ without any enzyme did not impact oil recovery using the heavy-fraction DDGS. Overall, fractionation and enzymatic hydrolysis showed promise to increase oil recovery from DDGS without any current ethanol plant design changes.
\end{abstract}

Keywords: oil recovery; enzymes; fractionation; temperature; DDGS

\section{Introduction}

Dried distillers grain with solubles (DDGS) is a co-product of the dry milling corn ethanol plant. According to the Renewable Fuels Association (2020) report, the ethanol industry produced nearly 396 million tons of DDGS using around 5.52 billion bushels of corn. Corn is the most expensive input for a dry grind plant, and the high volatility of corn prices (ranging from USD 2.00 to over USD 8.00 per bushel over the past ten years) has resulted in tight profit margins for the ethanol industry [1]. Therefore, the ethanol industry has recently centered on increasing the value of DDGS by manufacturing on-site value-added products. One of the most convenient ways to do this is by recovering oil from DDGS, as oil content in the DDGS can range from $9.1 \%$ to $14.1 \%$ based on different processing methods and corn variety [2]. DDGS is mainly used as animal feed. Since the value of animal feed is low compared to oil, the oil production from DDGS as a by-product of corn ethanol plants would help sustain and increase the ethanol industry's revenues [3,4]. Belyea et al. [5] reported that DDGS with high oil (13\%) and high protein (33\%) contents are worth USD 5-20 per ton more than original DDGS.

In aqueous oil extraction, enzymes have been used to increase oil yield by breaking the cell wall and membranes and hydrolyzing the emulsifying proteins [6]. Numerous efforts have been made to develop enzyme-based oil processing technologies from oilseeds, but the high cost of biocatalysts has slowed down technological adoption in the industry [7]. Enzyme-assisted aqueous extraction methods have been used to recover edible oil from different oil seeds and vegetables, reduce the use of organic solvents, and recover oil ranging from 53-97\% [8-10]. Though exogenous enzymes are used during the dry-grind 
process to improve ethanol yields, there is no published literature on increasing oil recovery from DDGS using commercial enzymes. Some research focused on extracting oil from condensed distiller grains (CDS), another co-product of ethanol plant, by using different enzymes and showed some effectiveness when enzymes were used in combination and when the particle size of CDS was reduced [11]. The same methods can be implemented to increase oil recovery from DDGS.

The efficiency of enzyme hydrolysis is expected to depend on the size of particles and cell distortion. Particle size reduction enhances the efficiency of enzyme diffusion rates acting on the substrates [8]. DDGS particle size ranges from 0.11 to $3.66 \mathrm{~mm}$ [12]. This high variability in particle size creates a common problem with the even distribution of nutrition in DDGS. Individual DDGS particles differ significantly in their chemical composition, size, shape, and density [13].

Fractionation effectively divides DDGS into different fractions of specific particle sizes to condense the oil content. Srinivasan et al. [14] sieved the DDGS into various sizes and then separated sieved fractions into different categories with airflow velocities and found it more effective than sieving alone in separating the fiber from DDGS. A bulk DDGS fractionation method for dividing bulk DDGS into high protein/oil and high fiber fractions could result in different applications for both fractions.

In this context, this research explores the possibility of using commercial enzymes separately and in combination to increase oil recovery from different fractions of DDGS. The objective of this study was to examine the effect of different commercial enzymes on oil recovery from the heavy fractions of DDGS. The commercial enzymes will be tested for achieving a high oil yield on heavy fractions of DDGS in the laboratory setting. This experiment will provide insight into how the enzymes influence oil recovery from the DDGS.

\section{Materials and Methods}

\subsection{Raw Materials and Chemicals}

The DDGS sample used in this experiment was collected from the Blue Flint Ethanol Plant (Underwood, ND, USA). The sample was stored at $4-6{ }^{\circ} \mathrm{C}$ until used in the experiment. The same batch of DDGS was used throughout the study to reduce the DDGS composition variability. Hexane ( $95 \%$ by volume) was purchased from Fisher Scientific (Fairlawn, NJ, USA).

\subsection{Fractionation of DDGS}

Fractionation of DDGS was completed using a standard sieve and lab aspirator. At first, the original DDGS was sieved into different sieve sizes, and then the sieved DDGS was aspirated separately. The sieving procedure was conducted based on the American Society of Agricultural Engineers (ASAE) standard method [15]. A $1.0 \mathrm{~kg}$ representative sample of DDGS, without any additional processing and moisture adjustment, was sent through selected US standard sieves of numbers 10, 20,40, and 60, and a pan fitted into a testing sieve shaker (Ro-Tap W. S. Tyler, Mentor, OH, USA) with shaking for five minutes. The mass of material retained on each sieve and the pan was weighed and recorded. The yield $(\%)$ of material retained on each sieve size was also calculated. The sieving procedure was repeated three times for each sample to produce enough sieved fractions for subsequent aspiration. Aspiration was performed using a KICE laboratory aspirator unit (Model 6DT41, KICE Metal Products Co. Inc., Wichita, KS, USA). DDGS was fed into the open feed hopper of the aspirator by gravity. The discharge of the feed hopper was equipped with an adjustable slide gate to regulate product flow. The air baffle was set at a 75-degree angle so that pressure at the inlet of the cyclone was a $6.35 \mathrm{~mm}(0.25 \mathrm{inch})$ water column. The aspirator divided the sieved sample into three major fractions: light, medium, and heavy fractions based upon density, weight, and particle size. There was also an insignificant dustier fraction, which was discarded. 


\subsection{Compositional Analysis of DDGS}

Compositional analysis of fractionated DDGS and original DDGS was conducted to see the effect of fractionation. The original DDGS is termed the "original" fraction, in contrast to sieved/aspirated fractions. The original DDGS samples and all fractions (sieved/aspirated) were measured for moisture, protein, and oil content using standard methods [16]. Moisture contents of DDGS samples were determined by drying in an oven at $105^{\circ} \mathrm{C}$ for $3 \mathrm{~h}$ (AOAC method 934.01). The combustion method was followed for determining protein content using a factor of 6.25 to convert percent nitrogen to percent protein (AOAC method 990.13). An accelerated solvent extractor (ASE200 solvent extractor, Dionex, Sunnyvale, CA, USA) was used to measure the oil content according to the official method [17]. In this AOCS method (method Am 5-04) for oil determination, $6 \mathrm{~g}$ of DDGS samples were mixed with approximately $2 \mathrm{~g}$ of diatomaceous earth and ground in a small grinder. The ground sample was loaded in $11 \mathrm{~mL}$ extraction cells. A cellulose filter was placed at the bottom of the $11 \mathrm{~mL}$ extraction cell before loading the sample. The extraction conditions were as follows: a pressure of $6895 \mathrm{KPa}(1000 \mathrm{psi})$, the temperature of $100{ }^{\circ} \mathrm{C}$, heat time of $5 \mathrm{~min}$, start time of $10 \mathrm{~min}, 3$ static cycles, $100 \%$ flush volume, and purge time of $60 \mathrm{~s}$. Upon completing the extraction, preweighed collection vials were placed in an evaporator with a water bath to evaporate the solvent. Then, the residue was weighed to determine the percent of the oil in the original sample. This oil quantification was used as the base to calculate oil recovery. The moisture content was used to convert concentrations of other components (crude protein and oil content) into a dry matter basis.

\subsection{Enzymes}

To investigate the influence of different enzymes on oil recovery from DDGS, commercial enzymes, NS50013 (cellulase complex), Cellic HTec (hemicellulase), and protease (AP1+) were used. Novozymes North America, Inc. (Franklinton, NC, USA) provided NS50013 and Cellic HTec. The protease was collected from a local bio-refinery. According to the manufacturer information sheet, the optimum temperature for cellulase complex NS50013 and Cellic HTec is in the range of $45-50{ }^{\circ} \mathrm{C}$ and $50-55^{\circ} \mathrm{C}$, respectively. Protease (AP1+) has a broad operating range for enhanced process flexibility and performs well within the temperature ranges typical in whole ground corn batch fermentations. Regarding operating $\mathrm{pH}$, the range for NS50013 was 4.5 to 6.5, protease was 3 to 5, and Cellic HTec was $4.75-5.25$.

\subsection{Design of Experiment}

The original DDGS sample was experimented with alongside protease, cellulase, and hemicellulase to explore the effect of different enzymes. All three enzymes were used both alone and in combination. Heavier fractions of number-20-sieved (sieved sample retained in number 20 sieve) and number-40-sieved DDGS (sieved sample retained in number 40 sieve) samples were selected for experiments based on their yield and composition (contained more oil than other samples). Protease and cellulase enzymes were applied alone and in combination with these fractionated DDGS samples. In all experiments, the temperature was set at $55^{\circ} \mathrm{C}$, and the control treatment had no enzyme but was treated with the same temperature condition $\left(55^{\circ} \mathrm{C}\right)$. Enzyme dosage was fixed at $5 \%(v / w)$. A follow-up experiment was conducted to explore the temperature effect on oil recovery. Original DDGS and the heavy fraction of 20-sieved DDGS were used with no enzyme condition but varying the operating temperature from $55-75^{\circ} \mathrm{C}$ in $5{ }^{\circ} \mathrm{C}$ intervals.

\subsection{Enzymatic Hydrolysis}

Enzyme hydrolysis was carried out at the optimum conditions for each of the enzymes, and each treatment was carried out in three replicates. Treatments were conducted in a $50 \mathrm{~mL}$ centrifuge tube using the calculated amount of DDGS to have at least $10 \mathrm{~g}$ of dry matter DDGS in the tube. The dry matter content of the DDGS was adjusted to $30 \%$ by adding the calculated amount of de-ionized water. The enzyme dosage was calculated 
based on the solids content (dry basis) of the DDGS. After adding the enzyme to the tube, the $\mathrm{pH}$ of the solution was checked. If the $\mathrm{pH}$ was less than 4.0, the buffer solution was used. Then, the $50 \mathrm{~mL}$ centrifuge tubes were heated up to specific temperatures (as described in Section 2.5) in a water bath shaker (MaxQ 7000, Thermo Scientific, Dubuque, IA, USA), and the tubes were kept in the water bath for three hours at $130 \mathrm{rpm}$.

\subsection{Oil Separation}

Oil was separated following enzyme hydrolysis by centrifugation $(8500 \times g)$ at $10,000 \mathrm{rpm}$ for 10 min (Allegra X-15R Benchtop Centrifuge, Beckman Coulter, Fullerton, CA, fitted with an FX6100 Fixed-Angle Aluminum Rotor, 25 degrees fixed angle, $6.65 \mathrm{~cm}$ radius at $11,200 \mathrm{rpm}, 11,400 \times \mathrm{g}$ ). Then, the top layer was washed several times using hexane. Some oil with solid residues was placed in the micro centrifuge tube and centrifuged at 10,000 rpm for $5 \mathrm{~min}$ (Galaxy 16 micro centrifuge, VWR International, Bristol, Conn, UK) to remove the solid residues. The hexane and oil mixtures were then transferred to pre-weighed round-bottom vials with transfer pipettes. The solvent was removed by an evaporation system equipped with a water bath (Microprocessor Controlled 280 Series, Thermo Electron Corporation) at $60^{\circ} \mathrm{C}$. Any residual solvent remaining in the mixture was removed using a vacuum oven. The weight of the oil was then determined gravimetrically. Oil recovery was calculated based on the oil content determined by the accelerated solvent extraction method for the specific fractions of DDGS used.

\subsection{Analysis of Defatted DDGS}

After oil separation, samples of defatted DDGS were analyzed for crude protein (CP), neutral detergent fiber (NDF), and acid detergent fiber (ADF). All samples were analyzed in the Nutrition Laboratory, Department of Animal Sciences, North Dakota State University. Two replicates from each sample were taken for these analyses. The combustion method was followed for determining protein contents using a factor of 6.25 to convert percent nitrogen to percent protein (method 990.13) [16]. Percent NDF and ADF were calculated using standard methods (method 2002.04 for NDF; method 973.18 for ADF) [16]. The moisture content of the samples was used to convert concentrations of these components $(\mathrm{CP}, \mathrm{NDF}$, and $\mathrm{ADF})$ into a dry matter basis.

\subsection{Statistical Analysis}

Each experiment was treated as an individual trial with a completely randomized treatment design. Statistical analysis was performed using the general linear model procedures of SAS 9.1 (Cary, NC, USA). Analysis of variance (ANOVA) was used to determine significant differences among the different treatments within an experiment. The least significant differences (LSD) test was also conducted for pair-wise comparisons when there was a significant effect at $p<0.05$ based on the ANOVA. All treatments were carried out in replicates, and results are reported as the means of replicates \pm standard deviation (SD).

\section{Results and Discussion}

\subsection{Effects of Fractionation}

The fractionation of DDGS was completed using standard sieving and a laboratory aspirator. Two primary determining factors of deciding a suitable portion for oil recovery need to be discussed-first, the yield of different DDGS fractions and second, the composition of a different fraction.

\subsubsection{Yield of Sieving}

Table 1 presents the yield percentage of DDGS in different sieves. DDGS was divided into four fractions, excluding the pan (above number 10, and between number 10-20, 20-40, and 40-60) by sieving. The particle sizes from the $0.42-0.84 \mathrm{~mm}$ sieve (US sieve no. 40 ) had the most occurrence, approximately $55 \%$, followed by the particle sizes from the $0.84-2 \mathrm{~mm}$ sieve, with approximately $22 \%$. 
Table 1. Yield of different fractions of DDGS in sieving operation.

\begin{tabular}{cccc}
\hline Sample & Us Sieve Size & Sieve Opening $(\mathbf{m m})$ & Yield $\mathbf{~ ( \% )}{ }^{*}$ \\
\hline 1 & $>$ No.10 & $>2.00$ & $1.80 \pm 0.40$ \\
2 & No. 20 & $0.84-2.00$ & $22.22 \pm 4.47$ \\
3 & No. 40 & $0.42-0.84$ & $55.44 \pm 11.58$ \\
4 & No. 60 & $0.15-0.42$ & $19.68 \pm 6.61$ \\
5 & $<$ No. 60 (Pan) & $<0.15$ & $0.73 \pm 0.03$ \\
\hline
\end{tabular}

${ }^{*}$ Mean of triple measurements \pm standard deviation.

This result contradicts Cheng et al. [18] and Regmi [19], where the highest yield was found in the particle size with the $0.84-2.00 \mathrm{~mm}$ sieve. However, the DDGS sample used for those experiments was much bigger (average size around $0.75 \mathrm{~mm}-0.78 \mathrm{~mm}$ ) than the DDGS sample used in the present study, which is around $0.5 \mathrm{~mm}$. DDGS particle size can differ greatly amongst the dry-grind ethanol plants. This variation occurs due to different processing techniques used in different ethanol plants. This is also an indication of the DDGS particle size variability that makes DDGS a challenging feedstock for oil recovery.

\subsubsection{Yield of Aspiration}

The original DDGS and the two highest yield sieved samples, samples 2 and 3 in Table 1, were further fractionated to three different fractions (heavy, medium, and light) using an aspirator. Table 2 indicates the yield percentage of different particles of DDGS with the aspirator's air baffle set at a $75^{\circ}$ angle with $6.35 \mathrm{~mm}(0.25 \mathrm{inch})$ water column pressure. Changing the air pressure had an impact on the yield and composition of different fractions of DDGS. The stated air pressure was selected from a preliminary experiment, which showed the heavier fraction was rich in oil content, and the lighter fraction was rich in fiber content. Srinivasan et al. [20] reported that a large sample of DDGS is required to have the right amount of fiber (4-15\%) depending on particle size, which can be separated from the whole sample.

Table 2. Yield of different fractions of DDGS in aspiration operation.

\begin{tabular}{ccc}
\hline Aspiration Sample & Fraction & Yield (\% Whole Fraction) ${ }^{*}$ \\
\hline \multirow{2}{*}{ Original DDGS } & Heavy & $12.42 \pm 3.67$ \\
& Medium & $77.40 \pm 5.67$ \\
& Light & $9.36 \pm 4.79$ \\
\hline \multirow{2}{*}{ Number-20-sieved DDGS } & Heavy & $41.41 \pm 6.05(9.29)$ \\
Sample 2 (retained on no. 20) & Medium & $44.36 \pm 4.15(9.86)$ \\
& Light & $12.84 \pm 8.67(2.85)$ \\
\hline \multirow{2}{*}{ Number-40-sieved DDGS } & Heavy & $8.10 \pm 4.39(4.44)$ \\
Sample 3 (retained on no. 40) & Medium & $70.75 \pm 2.80(39.23)$ \\
& Light & $18.54 \pm 7.40(10.28)$ \\
\hline
\end{tabular}

${ }^{*}$ Mean of triple measurements \pm standard deviation.

The heavy fraction yield of the original DDGS was about $12 \%$, whereas the medium fraction yield was about 77\% (Table 2). Interesting results were found when DDGS samples 2 and 3 from the sieving operation were aspirated. In both cases, the medium fraction had the highest yield of $44 \%$ and $70 \%$, respectively. For number- 40 -sieved DDGS (sample 3), the heavy fraction had the lowest yield. This shows that the DDGS sample had a smaller particle size in number-40-sieved DDGS (sample 3) than the original DDGS. However, a considerable yield of heavy and medium fractions was found in the number-20-sieved aspirated sample (41 and $44 \%$, respectively).

\subsubsection{Composition Variation in the Different Fractions of DDGS}

The variations in moisture, oil, and crude protein in different fractions of DDGS are illustrated in Figures 1-3, respectively. The moisture, oil, and protein content of each DDGS fraction were affected by the sieving and aspiration operations. The composition of 
these fractions shifted because the aspiration process separates the nutrients depending on their different densities. The straight-line in Figures 1-3 represents corresponding $Y$-axis properties such as moisture, oil, and protein content of the original DDGS sample, with whom the fractionation process was operated.

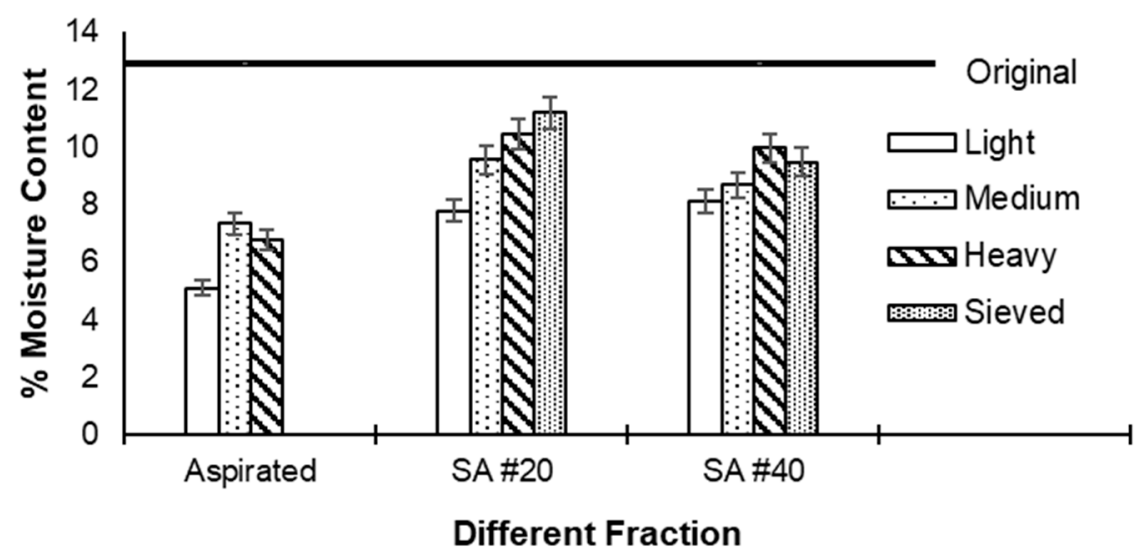

Figure 1. Moisture content variation of the different fractions.

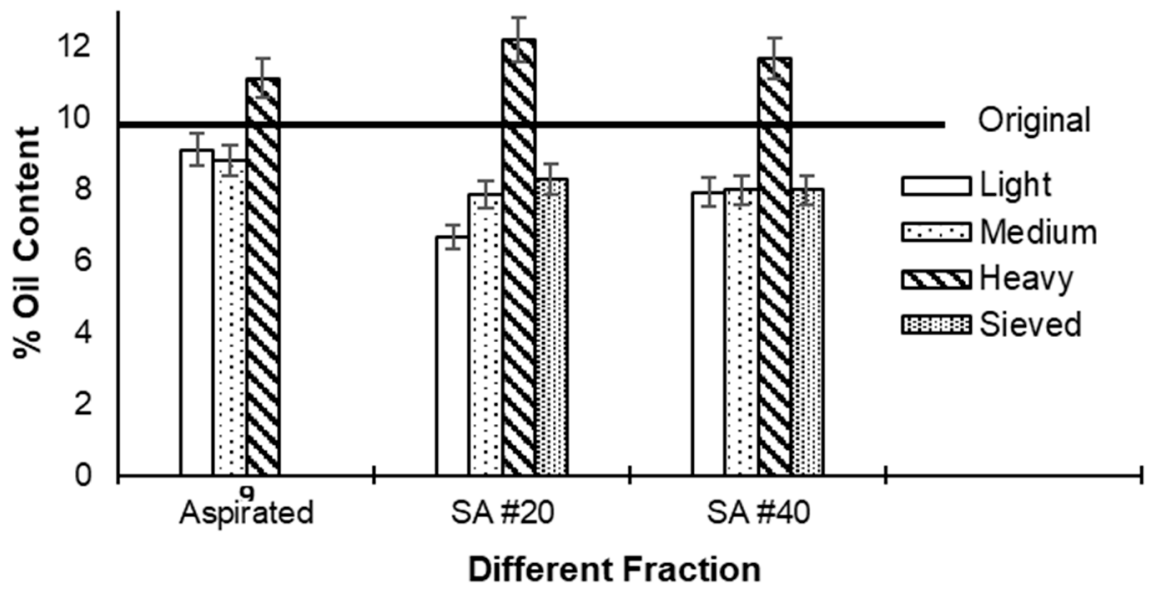

Figure 2. Oil content variation of the different fractions.

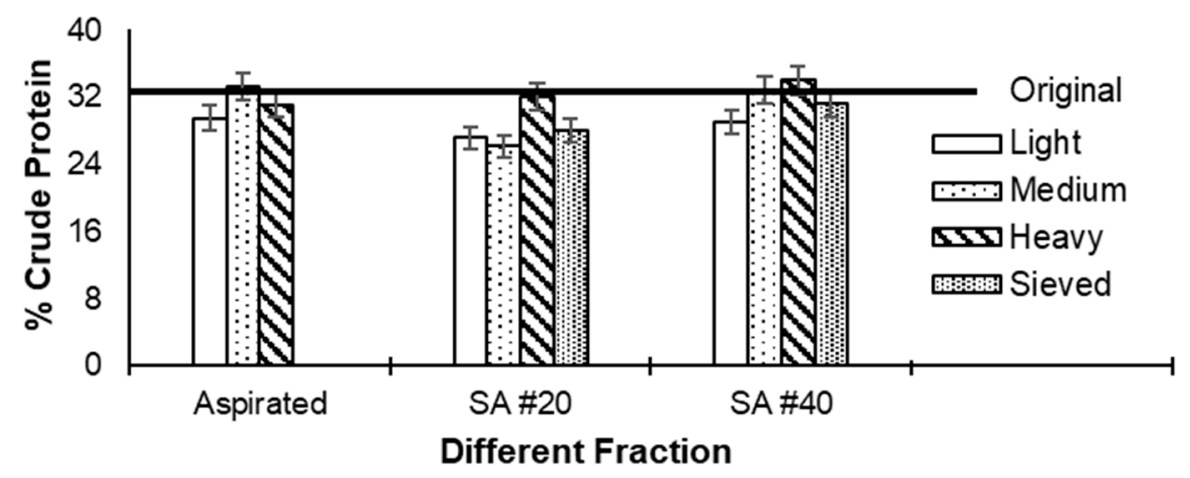

Figure 3. Crude protein variation of the different fractions.

The moisture content is reduced in the different fractions compared to the original DDGS because of the fractionation process (Figure 1). This is likely due to exposure to dry air in the lab during fractionation. Cheng et al. [18] explained that the lighter DDGS was blown further during aspiration, and the time DDGS was in contact with air was quite long, which suggests that aspiration can be regarded as a partial drying process. For oil content (Figure 2), the heavier fractions of aspirated (original sample), number 20 (sample 2), and number 40 (sample 3) DDGS had more oil content of 14, 24, and 19\%, 
respectively, compared to the original DDGS. This finding was quite similar to a study by Liu [21], who found that oil content in sized fractions for most DDGS samples had an upper trend with an increase in particle size. Crude protein increased in number 40 heavy fraction by $4 \%$ but reduced by $1.5 \%$ in number 20 heavy fraction (Figure 3 ) compared to the original DDGS. However, Srinivasan et al. [14] reported that fractions with smaller particles increased protein contents relative to the original DDGS, supporting the present findings.

After analyzing the yield and composition of different fractions of DDGS, two fractions were selected for further experimentation. They were number 20 (sample 2) and number 40 (sample 3), sieved aspirated heavy fraction DDGS samples (Figure 4). The differences in the physical appearances of the three different samples are visible in Figure 4. Number20-sieved aspirated heavy fraction DDGS (Figure 4b) had the darkest color, referring to more oil presence than other samples. Number-40-sieved aspirated heavy fraction DDGS (Figure 4c) had the smallest particle size among the three samples, showing a finer fraction than other samples.

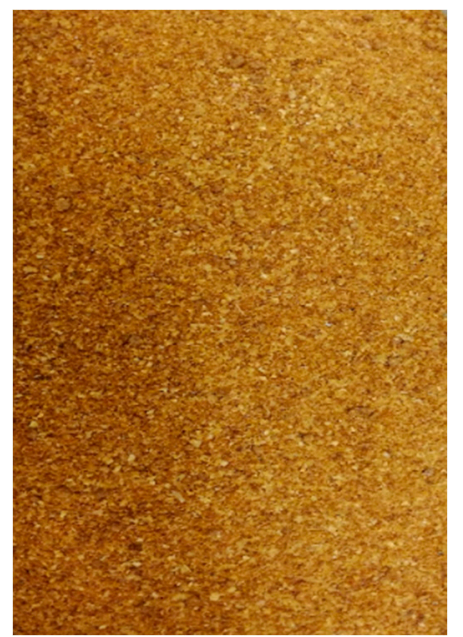

(a)

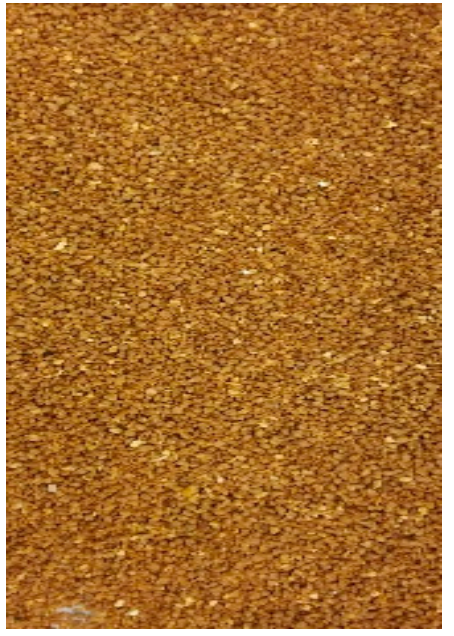

(b)

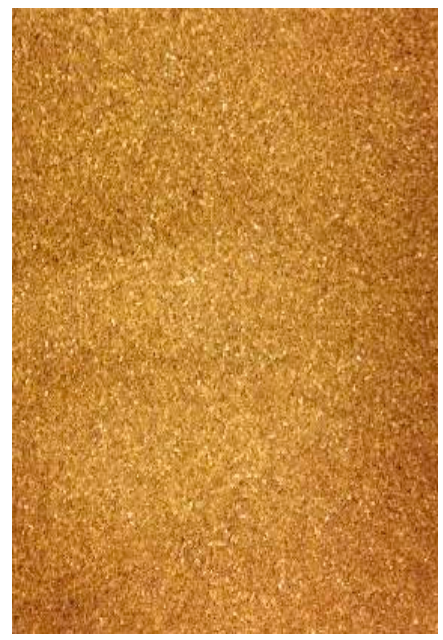

(c)

Figure 4. Samples used for different experiments; (a) original DDGS; (b) \#20-sieved aspirated (SA) heavy fraction; (c) \#40-sieved aspirated (SA) heavy fraction.

\subsection{Effects of Different Enzymes on Oil Recovery}

The oil content of the original DDGS was used to calculate oil recovery using protease, cellulase, and hemicellulase enzymes alone and in combination. The enzyme concentration was fixed at $5 \%(v / w)$ for all the treatments. The effect of different enzymes on oil recovery is shown in Table 3. The highest oil recovery of $94 \%$ occurred with the combined treatment of $5 \%$ protease, cellulase, and hemicellulase. However, it was not significantly different from the combined treatment of $5 \%$ protease and cellulase with $93 \%$ oil recovery. Oil recovered using only protease or cellulase was not substantially different between each treatment. The hemicellulase had the lowest impact on oil recovery.

Table 3. Effects of different enzymes (in single and combination) on oil recovery from original DDGS.

\begin{tabular}{ccc}
\hline Treatment $(\%$ Enzyme, $\boldsymbol{v} / \boldsymbol{w}){ }^{*}$ & ${\text { \% Oil } \pm \mathbf{S D}^{* *}}^{*}$ & \% Oil Recovery $^{*}$ \\
\hline 5\% Protease & $7.57 \pm 0.38_{\mathrm{b}}$ & 77.34 \\
$5 \%$ Cellulase & $7.35 \pm 0.11_{\mathrm{b}}$ & 75.03 \\
$5 \%$ Hemicellulase & $6.79 \pm 0.24_{\mathrm{c}}$ & 69.39 \\
$5 \%$ Protease $+5 \%$ Cellulase & $9.13 \pm 0.08_{\mathrm{a}}$ & 93.19 \\
$5 \%$ Protease + 5\% Cellulase + 5\% Hemicellulase & $9.23 \pm 0.13_{\mathrm{a}}$ & 94.29 \\
Control & $6.44 \pm 0.23_{\mathrm{c}}$ & 65.76 \\
\hline
\end{tabular}

* Enzyme dosage was based on the solids content of DDGS. ${ }^{* *}$ Means with different letters are significantly different $(p<0.05)$. 
The combination of protease and cellulase resulted in $28 \%$ more oil recovery than no enzyme treatment (Table 3). The cell wall of the corn kernel is comprised of hemicelluloses and celluloses but no pectin [22]; therefore, it was reasonable to use the cellulase and hemicellulase enzymes for oil recovery. However, Moreau et al. [6] observed that increasing levels of cellulases in corn germ cell wall components' hydrolysis did not show any obvious trend for increased oil recovery. This suggests that it may be necessary to use cellulases in combination with other enzymes to increase oil recovery significantly. Proteases hydrolyze the proteins and destabilize the oil-in-water emulsion, releasing free oil that can be separated and recovered. Since cellulases effectively break down the cell wall polysaccharides and facilitate oil body release [5], the oil may not have been freed without protease treatment. The control samples (no enzyme added) had around $65 \%$ oil recovery due to the incubation of samples in high temperatures that may break some of the DDGS oil-in-water emulsion that freed a small amount of oil.

\subsection{Effect of Different Fractions of DDGS on Oil Recovery}

Sieved aspirated heavy fraction DDGS (number 20 and 40-sieve size) was used for oil recovery using protease and cellulase enzymes in both single and combinations. As hemicellulase did not significantly affect oil recovery for the original DDGS (control sample), this enzyme was excluded for the oil recovery from the fractionated DDGS. Table 4 shows the result of oil recovery from both fractions of DDGS using both enzymes.

Table 4. Effects of different fractions of DDGS on oil recovery using enzymes.

\begin{tabular}{|c|c|c|}
\hline \multirow{2}{*}{ Treatment (\% Enzyme, $v / w) *$} & \multicolumn{2}{|c|}{$\begin{array}{c}\% \text { Oil Recovery } \pm \text { SD } * * \\
\text { (Sieved Aspirated Heavier Fraction of DDGS) }\end{array}$} \\
\hline & Sieve $20(0.841 \mathrm{~mm})$ & Sieve $40(0.420 \mathrm{~mm})$ \\
\hline $5 \%$ Protease & $87.23 \pm 1.03_{\mathrm{bc}}$ & $89.69 \pm 4.87 \mathrm{ab}$ \\
\hline $5 \%$ Cellulase & $95.19 \pm 3.61_{b}$ & $93.57 \pm 5.36 \mathrm{ab}$ \\
\hline $5 \%$ Protease $+5 \%$ Cellulase & $109.86 \pm 2.99 \mathrm{a}$ & $98.59 \pm 1.49 \mathrm{a}$ \\
\hline Control (no enzyme) & $85.67 \pm 4.91_{\mathrm{c}}$ & $83.61 \pm 4.76_{b}$ \\
\hline
\end{tabular}

The enzyme concentration was fixed at $5 \%(v / w)$ for all the treatments, as in the previous experiment. From Table 4, we can see that a combination of protease and cellulase did achieve nearly 100 percent oil recovery from both fractions. However, in one particular case, the oil recovery number overshoots more than 100 percent, which is unrealistic. It was probably due to the presence of very small debris in the crude oil that cannot be separated during oil recovery.

From Table 4, it is evident that protease did not work well on fractionated DDGS, having oil recovery not significantly different from the control sample. This was likely due to protease liberating the oil attached to solid surfaces such as cellular debris or proteins and emulsified oil droplets. The protease, however, did not make the oil more available for separation. On the other hand, cellulase worked very well on both fractions, recovering around $95 \%$ of the oil. Because adding cellulase opens up the cellular debris, releasing oil trapped in the complex cellulosic structure results in higher oil recovery.

Comparing the control treatments with the original DDGS showed that fractionation improved oil recovery significantly. Oil recovery was almost $20 \%$ higher in the control treatment of sieved aspirated heavy fractions than the original DDGS (Tables 3 and 4). Higher oil recovery in fractionated DDGS was probably due to the specific particle size of fractionated DDGS, which condensed the oil from the original DDGS by eliminating small and medium-sized fibers and other particles. The aspirated heavy fractions had more oil content, as already shown in Figure 2, which may have contributed to the high oil recovery. Previous literature also showed that oil contents are positively correlated with particle size [12], which supports the findings of this study. 


\subsection{Effect of Different Enzyme Treatments on the Composition of Defatted DDGS}

Sieved aspirated heavy fractions of DDGS (number 20 and 40 sieve size) were used to experiment with different enzyme effects on oil recovery. After recovering oil, the defatted DDGS was analyzed for crude protein (CP), natural detergent fiber (NDF), and acid detergent fiber (ADF). The variations of $\mathrm{CP}, \mathrm{NDF}$, and $\mathrm{ADF}$ are illustrated as bar graphs in Figures 5-7, respectively.

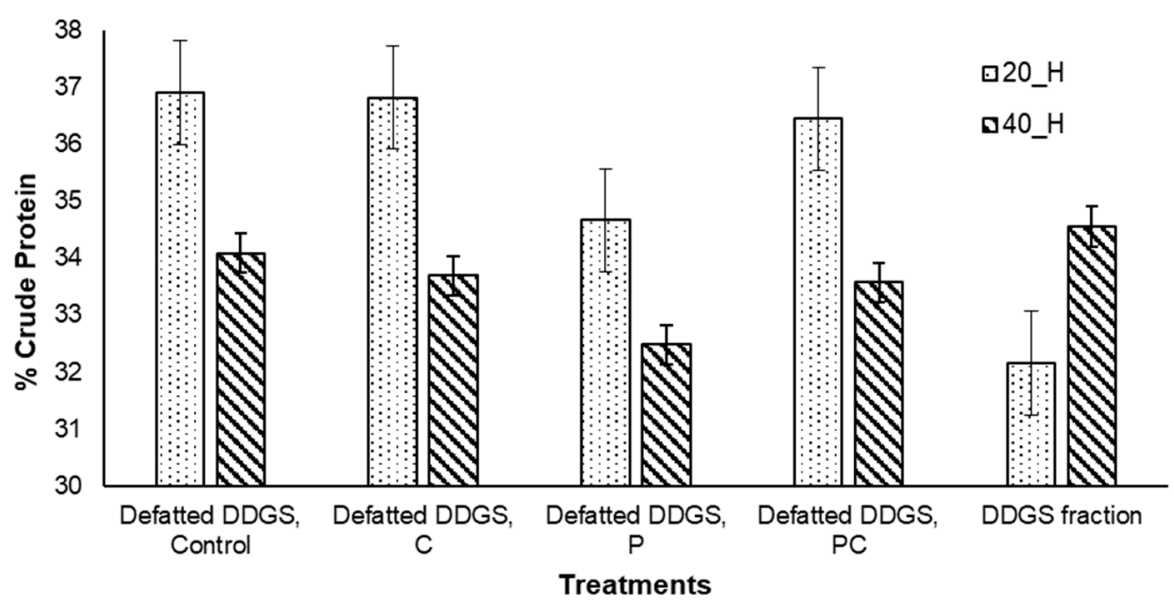

Figure 5. Effects of different enzymes on the crude protein variation in defatted DDGS (C-5\% cellulase; $\mathrm{P}-5 \%$ protease; $\mathrm{PC}-5 \%$ protease $+5 \%$ cellulase; control: no enzyme; fractions, $20 \_\mathrm{H}$ : number-20-sieved aspirated heavy fraction and 40_H: number-40-sieved aspirated heavy fraction).

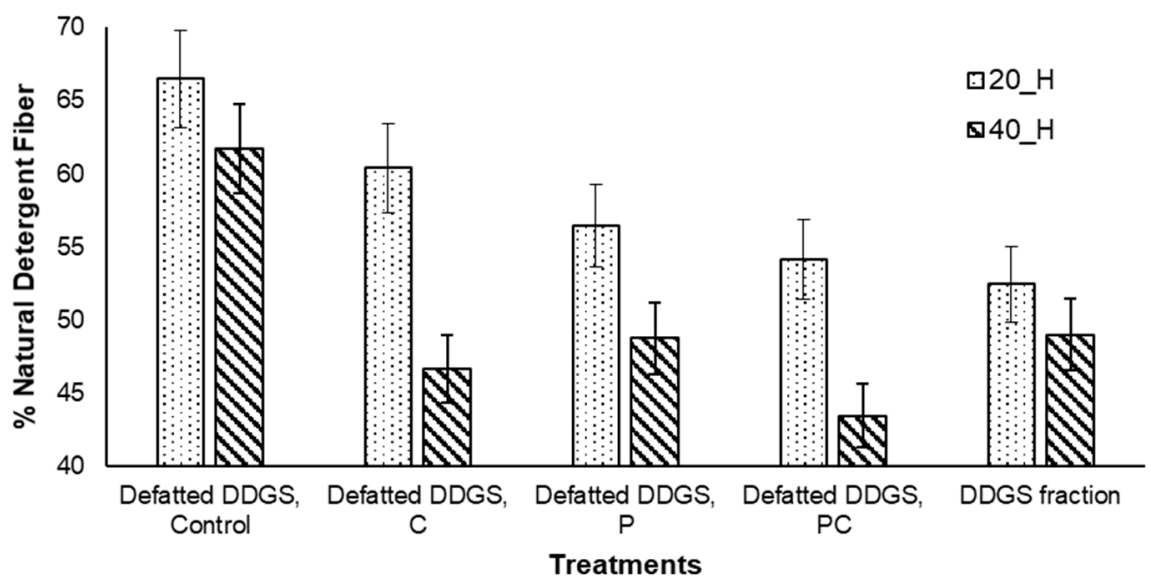

Figure 6. Effects of different enzymes on the NDF variation in defatted DDGS (C-5\% cellulase; $\mathrm{P}-$ $5 \%$ protease; $\mathrm{PC}-5 \%$ protease $+5 \%$ cellulase; control: no enzyme; fractions, $20 \_\mathrm{H}$ : number-20-sieved aspirated heavy fraction and 40_H: number-40-sieved aspirated heavy fraction).

Figure 5 shows that crude protein is reduced in the heavy fractions of the number-40sieved aspirated sample compared to the number-20-sieved aspirated heavy fraction. The percent crude protein amount ranges from 32 to $37 \%$ regardless of the treatments. More crude protein was observed in the number-20-sieved aspirated heavy fraction than the number 40 sample due to enzyme activity. Particle size plays an important role here. More protein may be hydrolyzed in the small-particle-size DDGS compared to large-particle-size DDGS. However, this did not have any effect on the oil recovery from these fractions. Proper crude protein levels are essential for the many types of livestock that rely on them for nutrition. When the percentage of $\mathrm{CP}$ is low, the bacteria responsible for digestion cannot sustain adequate levels to process forage. Ultimately, the animal's intake and digestibility are reduced. Therefore, enzyme treatments (including control; heat treatment 
only) in number-20-sieved aspirated heavy fraction DDGS did improve crude protein percent of the defatted DDGS.

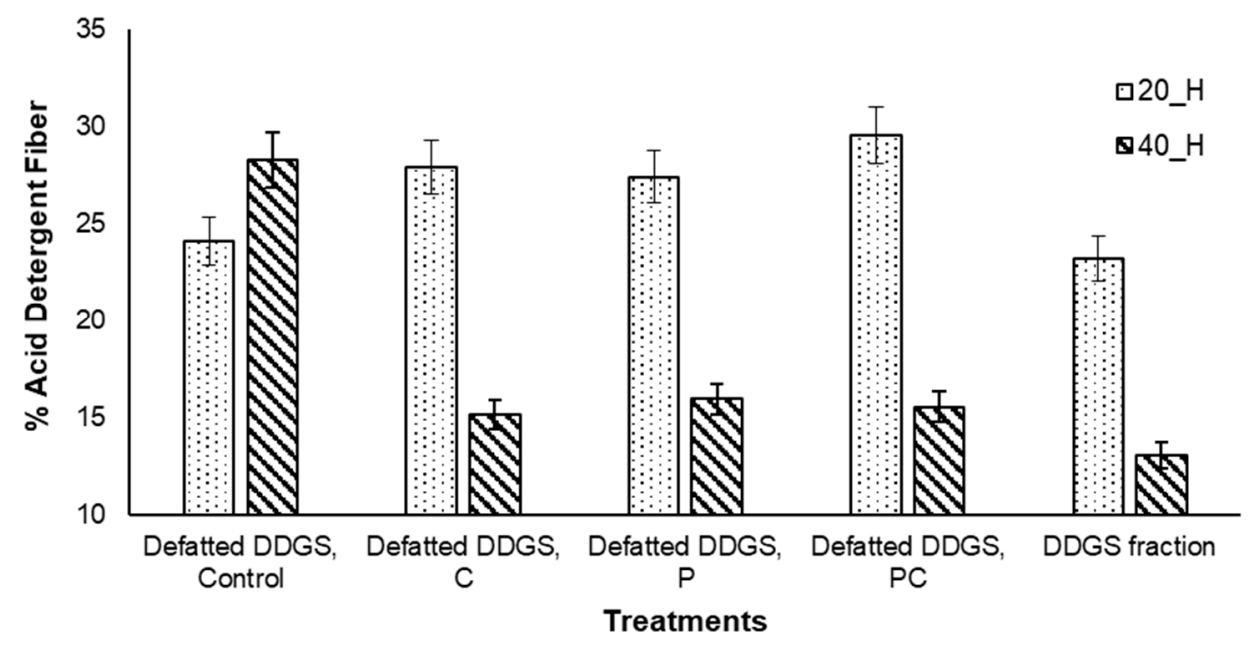

Figure 7. Effects of different enzymes on the ADF variation in defatted DDGS (C-5\% cellulase; $\mathrm{P}-$ $5 \%$ protease; $\mathrm{PC}-5 \%$ protease $+5 \%$ cellulase; control: no enzyme; fractions, $20 \_\mathrm{H}$ : number-20-sieved aspirated heavy fraction and 40_H: number-40-sieved aspirated heavy fraction).

For NDF content (Figure 6), the heavier fraction of aspirated numbers, 20 and 40 DDGS has less NDF than the control treatment. Reduced NDF is observed (except control) in the number-40-sieved aspirated heavy fraction after the enzymatic hydrolysis. However, the opposite trend is followed in the number-20-sieved aspirated heavy fraction after the enzymatic hydrolysis. No enzyme treatment (control) leads to a very high NDF content. As the NDF percent increases, generally, the dry matter intake and metabolic and digestive energy decrease, which is not favorable for a livestock feed requirement.

It is evident from Figure 7 that enzymes did work for decreasing ADF in number-40sieved aspirated heavy fraction and increasing ADF in number-20-sieved aspirated heavy fraction. However, increasing ADF reduces the ability to digest the feed. The difference between NDF and ADF is also a good indicator of feed product, reflecting the amount of hemicellulose in the feed product. This analysis found that (Figures 6 and 7) enzyme treatments with a combination of cellulase and protease resulted in lower hemicellulose than other treatments for both fractions. As hemicellulose content increases in animal feed, the voluntary feed intake typically decreases.

Enzyme treatments had a considerable impact on the variation of percent CP, NDF, and ADF values of the defatted DDGS. This outcome will undoubtedly help the biorefinery produce both oil and livestock feed products from DDGS to improve the economics of the ethanol plant.

\subsection{Effects of Temperature on Oil Recovery}

Based on previous experimental results (Section 3.3; Table 4), higher oil recovery (83-85\%) was found in control treatments of sieved aspirated heavy fraction. The control treatment had no enzymes and was only treated at the temperature of $55^{\circ} \mathrm{C}$. Therefore, we hypothesized that increasing temperature might increase oil recovery from the original and sieved aspirated heavy fraction. Because heating provides the energy required to break the emulsion and possibly weaken physical interactions between proteins and lipids or carbohydrates and lipids, oil recovery may increase [23]. To determine the effect of temperature on oil recovery, temperatures were increased with $5{ }^{\circ} \mathrm{C}$ intervals from $55^{\circ} \mathrm{C}$ up to $75^{\circ} \mathrm{C}$ and tested with sieved aspirated (SA\#20) heavy fraction and original DDGS.

Increasing the temperature over $55^{\circ} \mathrm{C}$ did not increase the oil recovery from any of the DDGS samples used (Figure 8). However, the decrease in oil recovery with increasing temperature did not decrease significantly $(p<0.05)$. The lowest oil recoveries were found 
at $65{ }^{\circ} \mathrm{C}$ and $70{ }^{\circ} \mathrm{C}$, for sieved aspirated (SA\#20) heavy fraction (77\%) and original DDGS $(55 \%)$, respectively. Another interesting point is that as the temperature increased above $65{ }^{\circ} \mathrm{C}$, more deviations in the oil recovery were found. This indicated that the oil recovery process was unstable as the temperature increased.

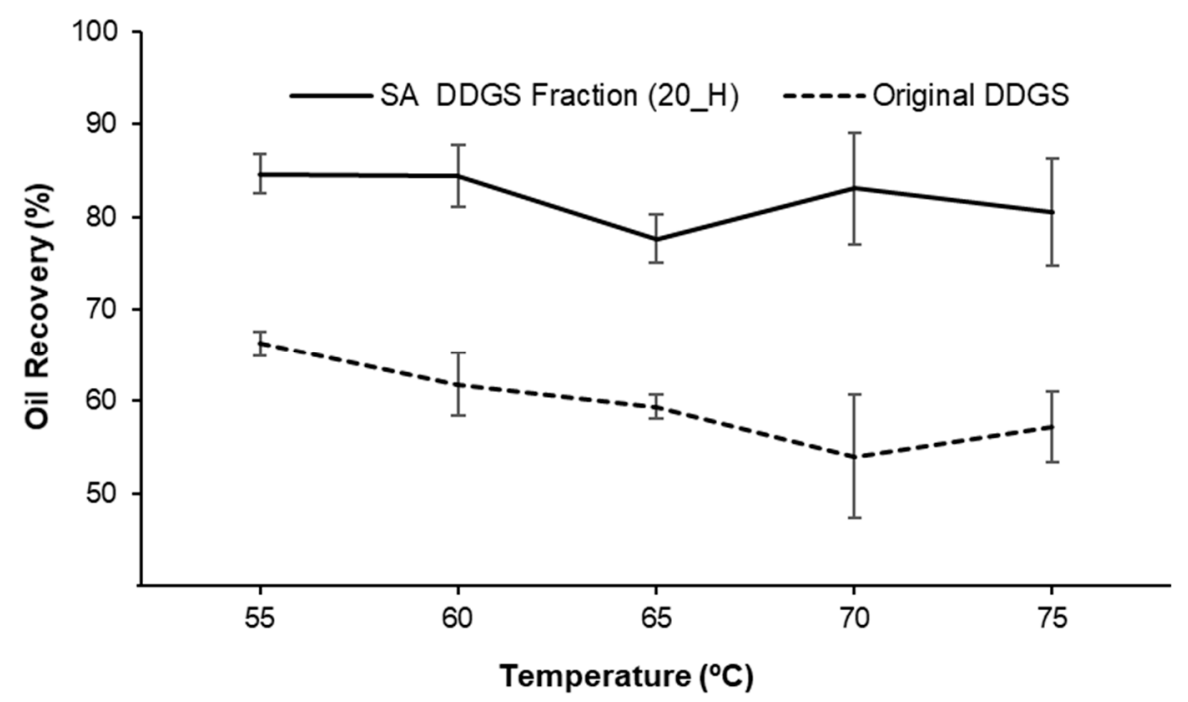

Figure 8. Effect of temperature on oil recovery from sieved aspirated (SA \#20), heavy fraction, and original DDGS.

These findings are comparable to Majoni et al. [24]. They found a rise in temperatures from $25{ }^{\circ} \mathrm{C}$ to $59{ }^{\circ} \mathrm{C}$ increased oil recovery from CDS. Most of the oil can be in the form of an oil-in-water emulsion containing proteins and phospholipids acting as emulsifiers. Heating is a practical way of demulsifying [25], when protein denaturation occurs. Thus, a temperature of $55^{\circ} \mathrm{C}$ resulted in the maximum rupture of the oil-in-water emulsion. As temperature rises, free minute oil droplets trapped on the hydrophobic surface and free intact oil bodies or oil bodies in intact cells are damaged by heating. Therefore, the free oil cannot be recovered. This may be the reason oil recovery did not increase with an increase in temperature.

\section{Conclusions}

Fractionation has a positive impact on the composition of the resulting fraction of DDGS, especially on the oil content of the original DDGS. Removal of fiber as a lighter fraction of DDGS could produce a new coproduct suitable for feeding nonruminants. Additional corn oil extracted from the heavy fraction of DDGS will lead to more biodiesel production and increased energy independence. Different types of enzymes were experimented with both alone and in combination, and the oil recovery results were compared with that from original DDGS. Despite the costs of enzymes, additional revenues from the oil can minimize those costs. At 5\% enzyme concentration, a combination of protease and cellulase resulted in the highest oil recovery similar to the combination of protease, cellulase, and hemicellulase. Therefore, there is no need for additional hemicellulase since it had a low impact on oil recovery. The combination of protease and cellulase increased oil recovery from original DDGS by $28 \%$ compared with no enzyme. However, the cellulase enzyme was similar to the combination of protease and cellulase by recovering more than $95 \%$ of oil from sieved aspirated heavy fractions. It will be more cost effective for the bio-refinery industry to use only one enzyme instead of combinations. When treated at $55{ }^{\circ} \mathrm{C}$ without enzymes, the oil recovery in the fractionated samples was increased by $20 \%$ compared to the original DDGS. Increasing the temperature after $55^{\circ} \mathrm{C}$, however, did not help to improve oil recovery. As enzymes have been used in dry-grind ethanol plants to boost ethanol production, it will be easy for the ethanol industry to use some enzymes in oil recovery from DDGS. The ethanol plants also had available tricanter, which can easily 
separate the oil after enzymatic hydrolysis. However, more efforts are required to scale this research up to the industrial scale. For future experimentation, different concentrations of enzymes and different operating conditions can be used to optimize the amount of enzyme for maximum oil recovery from DDGS.

Author Contributions: Conceptualization, M.S.H. and N.N.; Methodology, M.S.H., N.N., E.M. and S.R.; Software, M.S.H. and S.R.; Validation, M.S.H., N.N. and S.R.; Formal analysis, M.S.H. and N.N.; Resources, N.N. and E.M.; Data curation, M.S.H. and S.R.; Writing-original draft preparation, M.S.H.; Writing-review and editing, N.N., E.M. and S.R.; Visualization, M.S.H. and N.N.; Supervision, N.N.; Project administration, N.N.; Funding acquisition, N.N. All authors have read and agreed to the published version of the manuscript.

Funding: This work was partially supported by the USDA National Institute of Food and Agriculture Hatch project ND01476.

Data Availability Statement: The raw data presented in this study are available upon request.

Acknowledgments: The authors wish to thank Blue Flint Ethanol, LLC for providing the DDGS sample and Novozymes, Inc. for providing enzymes. The authors also would like to thank Andrew Taylor and Jennifer Longo of the North Dakota State University Center for Writers for their writing consultation to prepare the manuscript.

Conflicts of Interest: The authors declare no conflict of interest. The funders had no role in the design of the study; in the collection, analyses, or interpretation of data; in the writing of the manuscript, or in the decision to publish the results.

\section{References}

1. Renewable Fuels Association. Powered with Renewed Energy. Ethanol Industry Outlook. 2019. Available online: https:// ethanolrfa.org/wp-content/uploads/2019/02/RFA2019Outlook.pdf (accessed on 17 December 2020).

2. Liu, K. Chemical composition of distillers grains, a review. J. Agric. Food Chem. 2011, 59, 1508-1526. [CrossRef] [PubMed]

3. Chrenková, M.; Čerešňáková, Z.; Formelová, Z.; Poláčiková, M.; Mlyneková, Z.; Fl'ak, P. Chemical and nutritional characteristics of different types of DDGS for ruminants. J. Anim. Feed Sci. 2012, 21, 425-435. [CrossRef]

4. Jessen, H. Corn Oil Makes the Grade. The Ethanol Producer Magazine. 2013. Available online: http:/ / ethanolproducer.com/ articles/9755/corn-oil-makes-the-grade (accessed on 12 April 2021).

5. Belyea, R.L.; Rausch, K.D.; Tumbleson, M.E. Composition of corn and distillers dried grains with solubles from dry grind ethanol processing. Bioresour. Technol. 2004, 94, 293-298. [CrossRef] [PubMed]

6. Moreau, R.A.; Johnston, D.B.; Powell, M.J.; Hicks, K.B. A comparison of commercial enzymes for the aqueous enzymatic extraction of corn oil from corn germ. J. Am. Oil Chem. Soc. 2004, 81, 1071-1075. [CrossRef]

7. Gaur, R.; Sharma, A.; Khare, S.K.; Gupta, M.N. A novel process for extraction of edible oils: Enzyme assisted three phase partitioning (EATPP). Bioresour. Technol. 2007, 98, 696-699. [CrossRef] [PubMed]

8. Rosenthal, A.; Pyle, D.L.; Niranjan, K. Aqueous and enzymatic processes for edible oil extraction. Enzym. Microb. Technol. 1996, 19, 402-420. [CrossRef]

9. de Moura, J.M.L.N.; Johnson, L.A. Two-stage countercurrent enzyme-assisted aqueous extraction processing of oil and protein from soybeans. J. Am. Oil Chem. Soc. 2009, 86, 283-289. [CrossRef]

10. de Moura, J.M.L.N.; Campbell, K.; Mahfuz, A.; Jung, S.; Glatz, C.E.; Johnson, L. Enzyme-assisted aqueous extraction of oil and protein from soybeans and cream de-emulsification. J. Am. Oil Chem. Soc. 2008, 85, 985-995. [CrossRef]

11. Majoni, S.; Wang, T.; Johnson, L.A. Enzyme treatments to enhance oil recovery from condensed corn distillers solubles. J. Am. Oil Chem. Soc. 2011, 88, 523-532. [CrossRef]

12. Liu, K. Fractionation of distillers dried grains with solubles (DDGS) by sieving and winnowing. Bioresour. Technol. 2009, 100, 6559-6569. [CrossRef] [PubMed]

13. Bhadra, R.; Rosentrater, K.A.; Muthukumarappan, K. Cross-sectional staining and surface properties of DDGS particles and their influence on flowability. Cereal Chem. 2009, 86, 410-420. [CrossRef]

14. Srinivasan, R.; Moreau, R.A.; Rausch, K.D.; Belyea, R.L.; Tumbleson, M.E.; Singh, V. Separation of fiber from distillers dried grains with solubles (DDGS) using sieving and elutriation. Cereal Chem. 2005, 82, 528-533. [CrossRef]

15. ASAE. Method of Determining and Expressing Fineness of Feed Materials by Sieving; American Society Agricultural Engineers: St. Joseph, MI, USA, 2008. [CrossRef]

16. Horwitz, W.; Latimer, G. (Eds.) AOAC Official Methods of Analysis of AOAC International; AOAC International: Gaithersburg, MD, USA, 2010. Available online: http:/ / hdl.handle.net/10637/3158. (accessed on 25 June 2019).

17. AOCS. Rapid determination of oil/fat utilizing high temperature solvent extraction. AOCS Official Procedure Am 5-04; American Oil Chemists Society: Urbana, IL, USA, 2005. 
18. Cheng, M.H.; Riess, S.; Rosentrater, K.A. Fractionation of distillers dried grains with solubles (DDGS) by combination of sieving and aspiration. In Proceedings of the American Society of Agricultural and Biological Engineers, Montreal, QC, Canada, 13-16 July 2014; p. 1.

19. Regmi, S. Manufacturing Low-Density Particleboards from Wheat Straw and Distiller's Dried Grains with Solubles. Master's Thesis, North Dakota State University, Fargo, ND, USA, 2021.

20. Srinivasan, R.; To, F.; Columbus, E. Pilot scale fiber separation from distillers dried grains with solubles (DDGS) using sieving and air classification. Bioresour. Technol. 2009, 100, 3548-3555. [CrossRef] [PubMed]

21. Liu, K. Particle size distribution of distillers dried grains with solubles (DDGS) and relationships to compositional and color properties. Bioresour. Technol. 2008, 99, 8421-8428. [CrossRef]

22. Karlovic, D.J.; Bocevska, M.; Jakovlevic, J.; Turkulov, J. Corn germ oil extraction by a new enzymatic process. Acta Aliment. 1994, 23, 389-400.

23. Xu, W.; Reddy, N.; Yang, Y. An acidic method of zein extraction from DDGS. J. Agric. Food Chem. 2007, 55, 6279-6284. [CrossRef]

24. Majoni, S.; Wang, T.; Johnson, L.A. Physical and chemical processes to enhance oil recovery from condensed corn distillers solubles. J. Am. Oil Chem. Soc. 2011, 88, 425-434. [CrossRef]

25. Chabrand, R.M.; Kim, H.-J.; Zhang, C.; Glatz, C.E.; Jung, S. Destabilization of the emulsion formed during aqueous extraction of soybean oil. J. Am. Oil Chem. Soc. 2008, 85, 383-390. [CrossRef] 